\title{
ARTÍCULOS
}

\section{PRIVACY CONCERNS ABOUT INFORMATION SHARING AS TRADE-OFF FOR PERSONALIZED NEWS}

\section{Preocupación por la privacidad a la hora de compartir información a cambio de noticias personalizadas}

Idoia Portilla

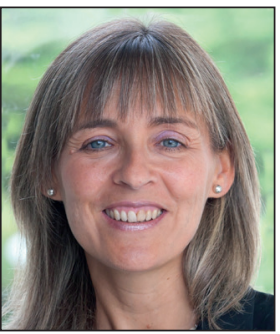

Abstract

In order to personalize news, the media must collect data from the audience. Media can establish a "datawall" for this task, which requires readers to share information to benefit from these valuable services. However, this may mean the loss of anonymity, and audience members may feel they are placing their privacy at risk. In this research, using data from the Digital news report 2016, we observe that online news audiences in Spain are worried about the privacy risks related to accessing personalized news. Their level of concern varies depending on demographic characteristics or how they access digital news. Media companies should take audience concerns into account because they do not want to lose audience trust in the process of capturing personal information for big data strategies.

\section{Keywords}

Big data; Datawall; Media; Personalized news; Audiences; Privacy; Personal information; Digital news report; Spain.

\section{Resumen}

Los medios de comunicación pueden establecer un muro de pago con datos (datawall) solicitando a los lectores que compartan información a cambio de beneficiarse de servicios como recibir noticias personalizadas. Sin embargo, esto puede significar la pérdida de anonimato, y los miembros de la audiencia pueden sentir que están poniendo en riesgo su privacidad. En esta investigación, utilizando datos del Digital news report 2016, observamos que las audiencias de noticias online en España están preocupadas por los riesgos de privacidad relacionados con el acceso a noticias personalizadas. Su nivel de preocupación varía atendiendo a sus características demográficas o a cómo acceden a las noticias digitales. Los medios de comunicación deben tener en cuenta estos resultados ya que la obtención de datos personales es esencial para implementar estrategias de datos masivos (big data), pero si no se realiza adecuadamente puede suponer perder la confianza de la audiencia.

\section{Palabras clave}

Big data; Datos masivos; Muro de pago; Medios; Noticias personalizadas; Audiencias; Privacidad; Información personal; Digital news report; España.

Portilla, Idoia (2018). "Privacy concerns about information sharing as trade-off for personalized news". El profesional de la información, v. 27, n. 1, pp. 19-26. 


\section{Introduction}

Every time a person accesses online news they leave a digital trail that the media can gather and analyze. The media can know the content that people find more interesting, when or how they use it, and offer personalized services and applications, making the content more attractive to the audience (Gómez-Barroso; Feijóo-González, 2013; Evens; Van-Damme, 2016) and, therefore increasing revenues. Media can also sell the information to advertisers, who can benefit from the information as well (Gómez-Barroso; Feijóo-González, 2013; Lee, 2016; Mulhern, 2016; McStay, 2017). All this information is big data and the media can monetize it (Nelson; Webster, 2016).

The value of the information increases with the inclusion of personal data. The "datawall", which requires information to access services (Evens; Van-Damme, 2016), can provide this personal information. But this wall creates a dilemma for the user: although they can receive personalized services tailored to their interests, they lose their privacy in return (Evens; Van-Damme, 2016).

This paper aims to observe if news readers in Spain are willing or unwilling to take risks in terms of their privacy in exchange for receiving personalized services from the media. We use the 2016 data of the Digital news report. http://www.digitalnewsreport.es

The results of this study will include recommendations for media companies considering big data strategies.

\section{Digitalization, data and media}

Digitalization has boosted data generation and personal information has become a commodity to be traded because it holds monetary value (Llorca-Abad; Cano Orón, 2016; Mai, 2016b). Nowadays, data can be used as a currency in digital business models (Evens; Van-Damme, 2016). Personal data is bought, sold, and traded among firms (Acquisti; Taylor; Wagman, 2016). And experts predict that incentives to monetize personal data will increase in the future (Lee, 2016).

Companies know the value of data and collect it in many ways. The most used methods of capturing data are online tracking cookies and website pathing (Forbes Insights, 2013), which confirms the relevance of internet use as a data source. Computers, mobile phones, tablets, and other technologies track all the activities in which internet users engage (Mai, 2016a; McStay, 2017). And each individual's activity, and the information they disclose, can be recorded, making it shareable and giving it commercial value (Jørgensen, 2016). We are already in the era of big data and, in the future, the number of connected devices will increase so that datafication might include "everything" (Mayer-Schönberger; Cukier, 2013; Sánchez-Alcón; López-Santidrián; Martínez, 2015; McStay, 2017).

Media industries are well-positioned to capture big data from their digital offerings (Napoli, 2016). In the case of news, media organizations can trace how their audience follows its content, where they read it, the success of headlines, or how far into stories they read (McStay, 2017). And this knowledge helps them to create personalized offerings, "such as recommended news articles, profiled subscription formulas, targeted advertising, and personalized Web store offerings" (Evens; Van-Damme, 2016, p. 29). With all this data, media can implement big data strategies for a better understanding and targeting of customers (Napoli, 2016). Data offers great opportunities to the communication market (Marks, 2013; Papí-Gálvez, 2014).

At the moment, digital media businesses are the ones making the most out of their data. This is the case of Netflix, Amazon TV, Hulu, and YouTube (Fernández-Manzano; Neira; Clares-Gavilán, 2016; Mateos, 2014). In the area of digital news, the HuffPo has employed big data analytics for passive personalization (connecting the right content to the right people using algorithms that identify user-level interest), and to study how individuals access their content with the goal of improving user experience on the website (Stone, 2014).

However, big data strategies are still a challenge for many media companies (Stone, 2014). They are even more important now that the media has been having problems getting revenue through other resources (Evens; Van-Damme, 2016; Portilla; Medina, 2016). Spanish media faces the same problem. According to the study of IME and Carat about the future of the digital press in Spain, the monetization of data is one challenge for Spanish newspapers (Murgich, 2017).

\section{The datawall and privacy}

Media organizations can collect personal data and track online behavior across online platforms and services using a datawall (Evens; Van-Damme, 2016). This kind of wall requires readers to share personal data to pass beyond it and obtain benefits.

It "is an analogy with paywalls, to secure access to a selection of (free) personalized news" (Evens; Van-Damme, 2016, p. 26)

or other personalized services. A datawall transforms anonymous users into registered ones.

If a news organization implements a datawall, it could benefit from big data analytics. But the benefit requires maximizing user experience by offering value-added personalized services (Evens; Van-Damme, 2016).

Several Forbes studies show the relationship between giving up personal data and the benefits obtained (Stone, 2014). Respondents said personal data collection yielded better products to meet their needs and it enabled better services; money and time were also important as an incentive to share personal information (Forbes Insights, 2013). Some users even provide information about their income in exchange for discounts (Gómez-Barroso; Feijóo-González, 2013).

In the news media, the success of a datawall depends on the predisposition of the people to pay with their personal data (Evens; Van-Damme, 2016; Jørgensen, 2016) so as to benefit from content and services. Therefore, the user's acceptance of sharing personal data with the organization is crucial (Evens; Van-Damme, 2016), paying with their "user consent to processing of personal data" for accessing the services (Jørgensen, 2016, p. 168). 
As Lee (2016) says, data monetization leads to the commodification of personal data and privacy. So, privacy concerns could undermine the acceptance of datawalls (Evens; Van-Damme, 2016).

The issue of privacy has been examined extensively in the area of direct marketing (Pope; Lowen, 2009), in health or family communication (Petronio, 2016), and as a main problem in our society generally (Morozov, 2013). It has also been studied for websites (Wu et al., 2012), social media (Marwick; Boyd, 2014; Yang; Pulido; Kang, 2016), and relating privacy with disclosure of personally identifiable information or intimacy (Sibilia, 2008; Tufekci, 2008; Tello, 2013; Zurbriggen; Hagai; Leon, 2016). However, privacy is a term hard to define (Solove, 2002; Acquisti; Taylor; Wagman, 2016).

According to Taddei and Contena (2013), privacy can be defined as a process of anonymity preservation. It can also be related to protection against access: to limit others from accessing personal information (Acquisti; Taylor; Wagman, 2016; Mai, 2016b). In this paper, we link both definitions and understand that privacy is: 1) strongly connected with control over information about the data user (Lessig, 2002; Taddei; Contena, 2013; Jørgensen, 2016), and 2) strongly connected with control over access to this information.

The media industries are well-positioned to capture big data from their digital offerings

\section{The privacy paradox and characteristics related to privacy concerns}

According to several studies, consumers try to protect their online privacy by using different strategies: they clear their browser history, refuse to provide information that is not relevant to a transaction, use temporary usernames or email addresses, or even give misleading information (Lee, 2016); they also interrupt a questionnaire when they feel they have to answer too many personal questions (Stone, 2014).

However, although the concern exists, consumers still give up personal information to access services or simply to share it publicly (Evens; Van-Damme, 2016; Lee, 2016). The users of social networks express private information through them, a phenomenon called "extimacy" (Sibilia, 2008; Tello, 2013). The contradictory interaction between reason and action has been referred to as the "privacy paradox": some people show great concern about invasion of privacy, while others freely give up personal information (Barnes, 2006).

Privacy concerns have been connected to demographic variables such as age, educational level, income, and gender. In the area of direct marketing, older consumers in Canada were more likely to provide bad data to protect their personal information, although results differed in the USA (Pope; Lowen, 2009). In general, consumption studies have found that the youngest consumers do not mind being watched, even though they trust businesses much less than older consumers (Forbes Insights, 2013). However, the protection of personal data online is more important for young people than for elders in Finland and Estonia (Sirkkunen, 2015).

Education also has an impact on disclosure, with more highly educated people being less likely to take action to protect their privacy (Pope; Lowen, 2009). Income has also been linked to privacy concerns (Van-Doorn; Verhoef; Bijmolt, 2007). Gender is also related to disclosure, with women showing more concern than men (Tufekci, 2008).

Another aspect that affects privacy concerns is one's feeling of control (McStay, 2017). Control and trust influence disclosure behavior (Taddei; Contena, 2013). People's willingness to share personal data is related to the extent to which they have control of their own data (The Boston Consulting Group, 2012), disclosing more personal information when privacy policies are clearly exposed, for example (Taddei; Contena, 2013).

Privacy and trust are strongly related (Wu et al., 2012; Verhoef; Kooge; Walk, 2016). Consumers are willing to share data with brands they trust (Evens; Van-Damme, 2016). Moreover, privacy, trust, control, and disclosure behaviors are all linked, but the relationship is complex (Taddei; Contena, 2013). Brands that give a greater feeling of control also increase trust, but the direction of causality is not yet clear (Pope; Lowen, 2009).

\section{Research questions}

This case study will focus on privacy concerns among internet users consuming news in Spain. The service that requires the disclosure of information is the personalization of news. Spanish online news readers may think that getting more personalized news means that their privacy is placed at greater risk.

The case of the media is especially interesting because long-standing news organizations are viewed as the most trustworthy brands, so the introduction of a datawall in the news' business model may be successful (Evens; Van-Damme, 2016). But, as we said before, a datawall can be viewed as risky in terms of privacy, and concern varies according to demographics. So, we will study this concern taking into account variables such as gender, age, income, and educational level. We also consider variables related to access and interest in news, because personalized news is the trade-off.

According to these ideas, the purpose of this research is answering the following questions:

1) Are news media users in Spain worried about placing their privacy at a greater risk as a result of using a personalized news service?

2) The perception of risk among readers of the news in Spain: Is it similar to the perception in other countries?

3) Is there any demographic or technic characteristic related to one's concern about privacy in this situation?

- The demographic characteristics will be gender, age, education, and income.

- The technic characteristics will be the frequency of accessing news, the interest in them, the device used, and how news is accessed (website, apps, alert systems...). 


\section{Method}

The data used in this research comes from the Digital news report, 2016.

http://www.digitalnewsreport.org/survey/2016

This study was managed by the Reuters Institute for the Study of Journalism of the University of Oxford (Newman et al., 2016). The dataset is available in SPSS format and researchers are able to request it after the publication of the annual report. The research company YouGov conducts the annual studies using an online panel.

In 2106, the fieldwork began at the end of January and finished in February.

http://www.digitalnewsreport.org/survey/2016/surveymethodology-2016

The data of the different countries were weighted to targets based on census/industry accepted data. The variables considered for weighting were age, gender, and region. The questionnaire asked about news consumption and consequently excluded people who said that they had not consumed any news in the past month. In Spain, the final sample reached 2,104 people (Newman et al., 2016).

The key question asked participants what their level of agreement was with the following statement: "I worry that more personalized news may mean that my privacy is placed at greater risk". The other selected questions are:

- Gender?

- How old are you?

- What is your highest level of education?

- What is your gross household income?

- Typically, how often do you access news? By news we mean national, international, regional/local news, and other topical events accessed via any platform (radio, TV, newspaper, or online).

- How interested, if at all, would you say you are in news?

- Which, if any, of the following devices do you ever use (for any purpose)?

- Which, if any, of the following devices have you used to access news in the last week?

- Thinking about how you got news online (via computer, mobile, or any device) in the last week, which were the ways in which you came across news stories?
The Reuters Institute also provides an Excel document with tables of all the variables and the comparison of column percentages. For each pair of columns, proportions are compared using a Z-test, analyzing if two values are significantly different at $p<0.05(I B M, s f)$. Once we have used the Chi-squared test to select the questions and options related with the level of agreement of the privacy statement, the Z-test will help us to understand which values differ and how.

\section{Results}

The analysis of the answers from the 2,104 readers of news in Spain shows that the level of agreement with the statement "I worry that more personalized news may mean that my privacy is placed at greater risk" is high. Taking into account the weighted data, $54.4 \%$ of Spanish respondents agree or strongly agree with this statement (see table 1 ).

The percentage of net agreement in Spain is similar to the figures for Hungary, Norway, Ireland, and Poland, but significantly higher than those from the rest of the countries studied in the Digital news report 2016 (see table 2).

\section{If a news organization implements a datawall, it could benefit from big data analytics}

\subsection{Demographics}

There is a significant relationship between the level of agreement with the statement about personalized news and privacy and three of the demographic variables: age (significant at $p<0.01$ ), gender, and income (significant at $p<0.05$ ). There is no relationship with educational level, which differs from the results of studies in other countries (Pope; Lowen, 2009), although the lower educational options had less than 100 cases, which can affect the Chi-squared test (Norušis, 1990).

The Z-test analysis for gender shows that the percentage of women that strongly agree with the statement is significantly higher than that of men ( $57 \%$ of who those who strongly agree are women) at $p<0.05$. This result agrees with previous studies (Tufekci, 2008).
The data for Spain was analyzed with the software SPSS. The statistical technique applied was the Chi-squared test, so as to study the dependence of two variables (Ross, 2010). In this case, the agreement with the key statement ("I worry that more personalized news may mean that my privacy is placed at greater risk") will be confronted with the other variables, many of them nominal variables that require this kind of test (Norušis, 1990). The purpose is to select the variables that are related to the key question.
Table 1. Privacy and personalized news in Spain. Digital news report 2016

\begin{tabular}{|c|c|c|c|c|}
\hline \multicolumn{5}{|c|}{$\begin{array}{l}\text { Spain - Level of agreement with the statement: I worry that more personalized news may } \\
\text { mean that my privacy is placed at greater risk }\end{array}$} \\
\hline Options & $\begin{array}{l}\text { Cases } \\
\text { (weighted data) }\end{array}$ & Percentage & $\begin{array}{l}\text { Aggregated } \\
\text { options }\end{array}$ & Percentage \\
\hline Strongly disagree & 94 & 4.5 & \multirow{2}{*}{ Net disagree } & \multirow{2}{*}{12.8} \\
\hline Tend to disagree & 175 & 8.3 & & \\
\hline Neither agree nor disagree & 690 & 32.8 & & \\
\hline Tend to agree & 657 & 31.2 & \multirow{2}{*}{ Net agree } & \multirow{2}{*}{54.4} \\
\hline Strongly agree & 488 & 23.2 & & \\
\hline
\end{tabular}

Source: Elaborated with data from the Digital news report 2016 of the Reuters Institute. 
Table 2. Privacy and personalized news by country. Digital news report 2016

Net agree (strongly agree and agree) with the statement: I worry that more personalized news may mean that my privacy is placed at greater risk

\begin{tabular}{|l|c|l|c|}
\hline \multicolumn{1}{|c|}{ Region } & $\begin{array}{c}\text { Percentage over people } \\
\text { that consumed any news } \\
\text { in the past month (1) }\end{array}$ & \multicolumn{1}{|c|}{ Region } & $\begin{array}{c}\text { Percentage over people } \\
\text { that consumed any news } \\
\text { in the past month (1) }\end{array}$ \\
\hline Hungary & 55 & Finland & $46^{*}$ \\
\hline Norway & 54 & Germany & $46^{*}$ \\
\hline Spain & 54 & Canada & $45^{*}$ \\
\hline Ireland & 54 & Republic of Korea & $45^{*}$ \\
\hline Poland & 52 & Japan & $44^{*}$ \\
\hline Austria & $51^{*}$ & Belgium & $43^{*}$ \\
\hline Australia & $50^{*}$ & Czech Republic & $43^{*}$ \\
\hline Greece & $50^{*}$ & Sweden & $41^{*}$ \\
\hline Portugal & $49^{*}$ & Italy & $40^{*}$ \\
\hline Switzerland & $49^{*}$ & Netherlands & $40^{*}$ \\
\hline UK & $49^{*}$ & France & $38^{*}$ \\
\hline US & $49^{*}$ & Denmark & $34^{*}$ \\
\hline Total population $(2)$ & & & $48^{*}$ \\
\hline
\end{tabular}

(1) The “*” means that there is a significant difference to the percentage in Spain.

(2) Turkey and Brazil are included in the population but not in the list because their samples referred only to urban population. It's interesting to note their figures were the highest ones: Brazil, 58\% of net agree and Turkey, 57\%.

Source: Data from the Excel document 2016 Reuters word used to elaborate the Digital news report (Newman et al., 2016).

Among the people that strongly agree with privacy concerns, $36 \%$ are 55 years old or older, a significantly high percentage. Among the people that disagree (disagree or strongly disagree) $16 \%$ are $18-24$ years old; only $8 \%$ of the people that agree with privacy concerns are in this age group. So, older people are more worried about their privacy than younger people. Other studies have also shown that young people share considerable information about themselves (Tufekci, 2008; Madden et al., 2013).

\section{A datawall requires readers to share per-} sonal data in order to obtain benefits

Although the Chi-square test indicates a relationship between income and the level of agreement with privacy concerns, the analysis of percentages doesn't show a clear conclusion. Some of the higher incomes ( $€ 40,000$ - $€ 44,999$; $€ 55,000$ - €59,999; €80,000 - €99,999; €100,000 - €149,999) show a high percentage of agreement with the statement, but not all of them.

\subsection{Frequency of access and interest in the news}

The level of agreement is related to the frequency of accessing news and the interest in them at $p<0.01$. The analysis of the frequencies shows that $42 \%$ of the people that agree with the statement access news once a day. Out of the people that disagree, $42 \%$ also access news once a day. Only the users that declare accessing news between 6 and 10 times a day have a significantly high concern about privacy.
Over the total sample of Spanish respondents, $84 \%$ declare that they are extremely or very interested in news. These news-fans are also the most frequent group over the people that agree with the privacy statement. The figure is significantly different only in comparison to the proportion of people that neither agree nor disagree. So, people interested in news seem to be more resolute about agreement or disagreement, but they do not show clear support for any of the extremes.

\subsection{Device and via used to ac- cess news}

Out of all the people that agree with the privacy concern statement, the group that uses a non-Apple smartphone or an eBook reader is the largest. Disagreement is high among people that use connected TV (a TV that connects to internet via a set top box, a gaming console, or another box such as Apple TV) and a smart watch or wristband that connects to the internet. The analysis of percentages also shows that the users of Apple devices, wristbands, and connected TVs seem to worry less about privacy when compared to other groups.

If the devices are used to access news within the last week, we also find a relationship between devices and the level of agreement with the statement. The people that strongly agree with privacy concern use a laptop or desktop computer or a non-Apple smartphone to access news. In terms of the people that disagree, meaning they show less concern about privacy, $27 \%$ of them access news using an Apple smartphone or tablet.

If a media company implements a datawall for any of their digital offerings, it must take into account how people will feel about disclosing their personal data

The Apple community seems to have a different opinion about privacy and/or a different behavior which makes them feel more comfortable with data disclosure. One reason could be that Apple users know the company has fought US federal demands to mine data from an iPhone (Nakashima, 2016). Other reasons could be that these users have peculiar demographic characteristics or are tech-savvy. More research is needed to fully understand these results.

Regarding how people get news online, the Chi-square test shows that people that directly access one or more news 
websites apps and those that get news via an email newsletter or email alert have given different answers when compared to other groups. However, the relevant one is in the first case: $47 \%$ of the people that strongly agree to worrying about privacy risk declare that they directly access news media apps. $38 \%$ of the Spanish population got news through apps, so their privacy concern is relevant.

Digital news readers have a higher concern about privacy in Spain as compared to other countries

\section{Limitations of the study and future research}

This study takes into account survey data and it lacks qualitative information that could help to understand the reasons behind some behaviors. As we saw before, qualitative data will be necessary to understand why Apple users feel more comfortable with data disclosure than other users.

Besides, it will be necessary to see if the level of concern about privacy changes after the application in May 2018 of the Regulation (EU) 2016/679 on data protection (European Parliament, 2016). This regulation will strengthen citizens' individual rights, giving them effective control over their personal data (Jourová, 2016), so their concern could lessen.

\section{Conclusions and recommendations for media}

Privacy is an ethical challenge (Zwitter, 2014) and also one of the most relevant legal aspects in any big data project (Pérez-Sanz, 2016). If a media company implements a datawall for any of their digital offerings, it must take into account how people will feel about disclosing their personal data.

Digital news readers in Spain had higher concerns about privacy when compared to other countries, according to the data from the Digital news report 2016. Although saying is not the same as doing, media companies should consider the implementation of datawalls in relationship to this information.

The Spanish users of Apple products showed lower concerns about privacy. If this is due to the device, the system could be imitated. The datawall for apps needs special attention because people that use them to access news are more worried about privacy than other users.

Concerns about privacy varies among news' users according to gender, age, and how they access online news, so media should implement their datawalls taking care of the data they collect.

As data collectors, there are four recommendations about the use of data that the media should follow:

- Media should only collect data that is relevant and congruent (ICC; Esomar, 2016; Verhoef; Kooge; Walk, 2016), and provide value that justifies the required data (Evens; Van-Damme, 2016; Verhoef; Kooge; Walk, 2016).

- They should be transparent, explaining the purposes of collecting data before doing it (Evens; Van-Damme, 2016;
ICC; Esomar, 2016; Mulhern, 2016; Pérez-Sanz, 2016; Verhoef; Kooge; Walk, 2016), and providing a clear privacy policy, adapted to the users (Lee, 2016).

- Media should transfer the control of the data to the users, a policy that substantially increases their willingness to share personal data (BCG, 2012). What is sensitive information differs between individuals (Pope; Lowen, 2009; Acquisti; Taylor; Wagman, 2016) and can change over time (Acquisti; Taylor; Wagman, 2016), so people need permanent control of the data they share.

- Finally, media companies should ensure data security and take all reasonable measures to prevent any data breach (ICC; Esomar, 2016).

Media should invest in brand trust to implement big data strategies (Verhoef; Kooge; Walk, 2016), and trust requires an adequate management of data, offering valuable services, being transparent, giving easy control of the data, and taking great care of it.

Media should invest in brand trust which requires adequate management of data, offering valuable services, transparency, and control of the data

\section{Acknowledgement}

This study is part of the project "Usos y preferencias informativas en el nuevo mapa de medios en España: audiencias, empresas, contenidos y gestión de la reputación en un entorno multipantalla" (Usprinme), funded by the Ministry of Economy and Competitiveness (Ministerio de Economía $y$ Competitividad) of Spain referenced with the number CSO2015-64662-C4-1-R.

\section{References}

Acquisti, Alessandro; Taylor, Curtis; Wagman, Liad (2016). "The economics of privacy". Journal of economic literature, v. 54, n. 2, pp. 442-492.

https://doi.org/10.2139/ssrn.2580411

Barnes, Susan B. (2006). "A privacy paradox: Social networking in the United States". First Monday, v. 11, n. 9. http://firstmonday.org/article/view/1394/1312_2

BCG (2012). The value of our digital identity. Liberty Global; The Boston Consulting Group (BCG).

European Parliament (2016). "Regulation (EU) 2016/679 of the European parliament and of the council of 27 April 2016 on the protection of natural persons with regard to the processing of personal data and on the free movement of such data". Official journal of the European Union, v. 59, 4 May. http://eur-lex.europa.eu/legal-content/EN/TXT/?uri=OJ:L:2016:119:TOC

Evens, Tom; Van-Damme, Kristin (2016). "Consumers' willingness to share personal data: Implications for newspapers' business models". International journal on media management, v. 18, n. 1, pp. 25-41.

https://doi.org/10.1080/14241277.2016.1166429 
Fernández-Manzano, Eva-Patricia; Neira, Elena; Clares-Gavilán, Judith (2016). "Data management in audiovisual business: Netflix as a case study". El profesional de la información, v. 25, n. 4, pp. 568-577.

https://doi.org/10.3145/epi.2016.jul.06

Forbes Insights (2013). The promise of privacy: Respecting consumers' limits while realizing the marketing benefits of big data.

https://images.forbes.com/forbesinsights/StudyPDFs/turn_ promise_of_privacy_report.pdf

Gómez-Barroso, José-Luis; Feijóo-González, Claudio (2013). "Información personal: la nueva moneda de la economía digital”. El profesional de la información, v. 22, n. 4, pp. 290-297. https://doi.org/10.3145/epi.2013.jul.03

IBM (sf). "SPSS statistics. Comparing column proportions". IBM Knowledge Center.

https://www.ibm.com/support/knowledgecenter/en/ SSLVMB_20.0.0/com.ibm.spss.statistics.help/sig_tests_ colprop_ex.htm

ICC; Esomar (2016). ICC/Esomar international code on market, opinion and social research and data analytics. International Chamber of Commerce; Esomar World Research.

https://www.esomar.org/uploads/public/knowledgeand-standards/codes-and-guidelines/ICCESOMAR_Code_ English_.pdf

Jørgensen, Rikke F. (2016). “The right to privacy under pressure". Nordicom review, v. 37, pp. 165-170.

http://www.nordicom.gu.se/sites/default/files/kapitelpdf/10.1515_nor-2016-0030.pdf

Jourová, Věra (2016). "How does the data protection reform strengthen citizens' rights?". Fact sheet, January, European Commission.

http://ec.europa.eu/justice/data-protection/document/ factsheets_2016/factsheet_dp_reform_citizens_ rights_2016_en.pdf

Lee, Laurie T. (2016). "Privacy: Future threat or opportunity?". In: Brown, Ruth; Jones, Valerie; Wang, Ming (eds.). The new advertising. New media, new uses, new metrics. v. 2, pp. 337-352. ISBN: 9781440833434

Lessig, Lawrence (2002). "Privacy as property". Social research, v. 69, n. 1, pp. 247-269.

https://muse.jhu.edu/article/557278/pdf

Llorca-Abad, Germán; Cano-Orón, Lorena (2016). “How social networks and data brokers trade with private data". Redes.com: revista de estudios para el desarrollo social de la comunicación, n. 14, pp. 84-103.

http://revista-redes.hospedagemdesites.ws/index.php/ revista-redes/article/view/454

Madden, Mary; Lenhart, Amanda; Cortesi, Sandra; Gasser, Urs; Duggan, Maeve; Smith, Aaron; Beaton, Meredith (2013). "Teens, social media, and privacy". Pew Research Center. Internet \& technology, 21 May.

http://www.pewinternet.org/2013/05/21/teens-socialmedia-and-privacy

Mai, Jens-Erik (2016a). "Big data privacy: The datafication of personal information". The information society, v. 32, n. 3, pp. 192-199.

http://jenserikmai.info/Papers/2016_BigDataPrivacy.pdf https://doi.org/10.1080/01972243.2016.1153010

Mai, Jens-Erik (2016b). "Three models of privacy. New perspectives on informational privacy". Nordicom review, v. 37, pp. 171-175.

http://www.nordicom.gu.se/sites/default/files/kapitelpdf/10.1515_nor-2016-0031.pdf

Marks, Richard (2013). The big opportunity: Audience research meets big data. London: IPA.

http://www.ipa.co.uk/document/The-Big-Opportunity-FullReport\#.WhxCV7QtUUE

Marwick, Alice E.; Boyd, Danah (2014). "Networked privacy: How teenagers negotiate context in social media". New media \& society, v. 16, n. 7, pp. 1051-1067.

https://doi.org/10.1177/1461444814543995

Mateos, Fátima (2014). Tendencias en el sector media. Icemd Future Trends Research.

https://www.icemd.com/digital-knowledge/estudios/ tendencias-en-el-sector-media

Mayer-Schönberger, Viktor; Cukier, Kenneth (2013). Big data: a revolution that will transform how we live, work, and think. Boston: Houghton Mifflin Harcourt. ISBN: 9781 848547933

McStay, Andrew (2017). Privacy and the media. Los Angeles: Sage. ISBN: 9781473924932

Morozov, Evgeny (2013). "The real privacy problem". MIT technology review, 22 October.

https://www.technologyreview.com/s/520426/the-realprivacy-problem

Mulhern, Frank J. (2016). "Big data and the digital transformation in advertising". In: Brown, Ruth; Jones, Valerie; Wang, Ming (eds.). The new advertising. Branding, content, and consumer relationships in the data-driven social media era, v. 1, pp. 95-108. ISBN: 9781440833427

Murgich, Valeria (2017). “¿Cuál es el futuro de la prensa digital en España?”. Merca2.0, 1 marzo.

https://www.merca20.com/la-prensa-digital-en-espana

Nakashima, Ellen (2016). "Apple vows to resist FBI demand to crack iPhone linked to San Bernardino attacks". The Washington Post, February 17.

https://goo.gl/wtd1nm

Napoli, Philip M. (2016). "Special issue introduction: Big data and media management". International journal on media management, v. 18, n. 1, pp. 1-7. https://doi.org/10.1080/14241277.2016.1185888

Nelson, Jacob L.; Webster, James G. (2016). “Audience currencies in the age of big data". International journal on media management, v. 18, n. 1, pp. 9-24.

https://doi.org/10.1080/14241277.2016.1166430

Newman, Nic; Fletcher, Richard; Levy, David A. L.; Nielsen, Rasmus K. (2016). Reuters Institute digital news report 2016. Reuters Institute for the Study of Journalism. 
http://reutersinstitute.politics.ox.ac.uk/sites/default/files/ research/files/Digital\%2520News\%2520Report\%25202016.pdf

Norušis, Marija J. (1990). SPSS introductory statistics: student guide. Chicago: SPSS Inc. ISBN: 013178062 X

Papí-Gálvez, Natalia (2014). "Los medios online y la ¿crisis? de la planificación de medios publicitarios". adComunica, n. 7, pp. 29-48.

http://www.adcomunicarevista.com/ojs/index.php/ adcomunica/article/view/166

Pérez-Sanz, Carlos (2016). "Aspectos legales del big data". Índice, v. 68, pp. 18-21.

http://www.revistaindice.com/numero68/p18.pdf

Petronio, Sandra (2016). "Communication privacy management”. In: Jensen, Klaus B.; Craig, Robert T.; Pooley, Jefferson D.; Rothenbuhler, Eric W. (eds.). The international encyclopedia of communication theory and philosophy, pp. 6-14. ISBN: 9781118290736

Pope, Jennifer A.; Lowen, Aaron M. (2009). "Marketing implications of privacy concerns in the US and Canada". Direct marketing: An international journal, v. 3, n. 4, pp. 301-326. https://goo.gl/Luce6f https://doi.org/10.1108/17505930911000883

Portilla, Idoia; Medina, Mercedes (2016). “Monetization strategies and audience data for online video. The case of Atresmedia". Quaderns del CAC, v. 19, n. 42, pp. 27-36. https://dadun.unav.edu/handle/10171/41989

Ross, Sheldon M. (2010). Introductory statistics. Burlington: Academic Press. ISBN: 9780123743886

Sánchez-Alcón, José-Antonio; López-Santidrián, Lourdes; Martínez, José-Fernán (2015). "Solución para garantizar la privacidad en internet de las cosas". El profesional de la información, v. 24, n. 1, pp. 62-70.

https://doi.org/10.3145/epi.2015.ene.08

Sibilia, Paula (2008). La intimidad como espectáculo. Buenos Aires: Fondo de Cultura Económica. ISBN: 978950557 7545

http://cmap.javeriana.edu.co/servlet/SBReadResourceServl et?rid=1J2SK927M-22DBXQG-1TB

Sirkkunen, Esa (2015). Report on the results of the privacy survey. Research Centre for Journalism, Media and Communication (Comet), the Priano project. University of Tampere.

Solove, Daniel J. (2002). "Conceptualizing privacy". California law review, v. 90, n. 4, pp. 1087-1155.

http://scholarship.law.berkeley.edu/cgi/viewcontent. cgi? article $=1408 \&$ context $=$ californialawreview

Stone, Martha L. (2014). Big data for media. Reuters Insti- tute for the Study of Journalism.

https://reutersinstitute.politics.ox.ac.uk/our-research/bigdata-media

Taddei, Stefano; Contena, Bastianina (2013). "Privacy, trust and control: Which relationships with online self-disclosure?". Computers in human behavior, v. 29, n. 3, pp. 821826.

https://doi.org/10.1016/j.chb.2012.11.022

Tello, Lucía (2013). “Intimidad y 'extimidad' en las redes sociales. Las demarcaciones éticas de Facebook". Comunicar, v. 21, n. 41 , pp. 205-213.

https://doi.org/10.3916/C41-2013-20

Tufekci, Zeynep (2008). "Can you see me now? Audience and disclosure regulation in online social network sites". Bulletin of science, technology \& society, v. 28, n. 1, pp. 20-36. https://goo.gl/rjTdWq https://doi.org/10.1177/0270467607311484

Van-Doorn, Jenny; Verhoef, Peter C.; Bijmolt, Tammo H. A. (2007). "The importance of non-linear relationships between attitude and behaviour in policy research". Journal of consumer policy, v. 30, n. 2, pp. 75-90. https://doi.org/10.1007/s10603-007-9028-3

Verhoef, Peter C.; Kooge, Edwin; Walk, Natasha (2016). Creating value with big data analytics: Making smarter marketing decisions. London; New York; Routledge. Taylor and Francis Group. ISBN: 9781138837973

https://goo.gl/NKc7Ue

Wu, Kuang-Wen; Huang, Shaio-Yan; Yen, David C.; Popova, Irina (2012). "The effect of online privacy policy on consumer privacy concern and trust". Computers in human behavior, v. 28, n. 3, pp. 889-897.

https://doi.org/10.1016/j.chb.2011.12.008

Yang, Kenneth C. C.; Pulido, Amanda; Kang, Yowei (2016). "Exploring the relationship between privacy concerns and social media use among college students: A communication privacy management perspective". Intercultural communication studies, v. 25, n. 2, pp. 46-62.

http://studyres.com/doc/6333946/exploring-therelationship-between-privacy-concerns-and-s...

Zurbriggen, Eileen L.; Hagai, Ella-Ben; Leon, Gabrielle (2016). "Negotiating privacy and intimacy on social media: Review and recommendation". Translational issues in psychological science, v. 2, n. 3, pp. 248-260.

http://dx.doi.org/10.1037/tps0000078

Zwitter, Andrej (2014). "Big data ethics". Big data \& society, v. 1, n. 2, pp. 1-6.

https://doi.org/10.1177/2053951714559253 